\title{
COMMENT
}

\section{Appropriate scales and data to manage seabird-fishery interactions: Comment on Torres et al. (2013)}

\author{
John Croxall ${ }^{1}$, Cleo Small ${ }^{2, *}$, Ben Sullivan ${ }^{2}$, Ross Wanless ${ }^{3}$, Esteban Frere ${ }^{4}$, \\ Ben Lascelles ${ }^{1}$, Ivan Ramirez ${ }^{5}$, Mayumi Sato ${ }^{6}$, Oli Yates ${ }^{7}$ \\ ${ }^{1}$ Global Seabird Programme, BirdLife International, Wellbrook Court, Girton Road, Cambridge CB3 0NA, UK \\ ${ }^{2}$ Royal Society for the Protection of Birds, The Lodge, Sandy, Bedfordshire SG19 2DL, UK \\ ${ }^{3}$ Seabird Division, BirdLife South Africa, PO Box 7119, Roggebaai 8012, South Africa and Percy FitzPatrick Institute, \\ DST-NRF Centre of Excellence, University of Cape Town, Private Bag, Rondebosch 7701, South Africa \\ ${ }^{4}$ Global Seabird Programme, BirdLife International, Matheu 1246/8, (C1249AAB) Buenos Aires, Argentina \\ ${ }^{5}$ Sociedade Portuguesa para o Estudo das Aves, Avenida João Crisóstomo, 18 - $4^{\circ}$ Dto., 1000-179 Lisboa, Portugal \\ ${ }^{6}$ BirdLife International Asia Divison, TM Suidobashi Bldg., 4F, Misaki-cho 2-14-6, Chiyoda-ku, Tokyo, Japan \\ ${ }^{7}$ BirdLife International Global Seabird Programme, Casilla 145, La Serena, Chile
}

\begin{abstract}
Torres et al. (2013; Mar Ecol Prog Ser 473:275-289) use fine-scale data on tracked locations of one species of albatross and fishing vessels to make a variety of assertions on interactions between them, especially in relation to risk of bycatch. Some of these assertions are incorrect, and we seek to clarify the issues and perspectives involved. We argue that while a fine-scale approach can provide interesting insights into foraging behaviour, large-scale risk analysis is needed because management measures (e.g. for bycatch mitigation) need to operate across all vessels in a fishery and across all seabird species at risk from the fishing operation. In addition, an estimate of $10 \%$ time spent in close proximity to vessels cannot be used to infer low bycatch risk alone: such an inference would need comparison to bycatch rate data. The analysis also does not take into account a number of factors known to affect the nature and duration of the association of albatrosses with fishing vessels, which limits the conclusions that can be drawn. However, finescale studies can provide important insight into factors affecting individual bycatch events, and studies at fine and broad scales will be complementary.
\end{abstract}

KEY WORDS: Bycatch $\cdot$ Satellite tracking $\cdot$ Albatrosses

\section{Introduction}

Torres et al. (2013) use fine-scale tracking data of an albatross species and periodic locations of fishing vessels, in waters off southern New Zealand, to infer interactions between the birds and the vessels. They assume that such interactions would be a good proxy for bycatch risk. On this basis they conclude that assessment of risk of interaction between seabirds and fishing vessels is better undertaken by inferring interactions at the level of individual seabirds and vessels than by assessment at the scale of fisheries and seabird populations. This represents a misunderstanding of the properties and utilities of fine-scale and larger scale analysis in relation to pragmatic management of fisheries at appropriate scales.

In addition, Torres et al. (2013) assert that conservation strategies, such as the reduction of non-target bycatch in commercial fisheries, should 'minimize 
burden on the fishing industry' (p. 276). We view the reduction of bycatch of non-target species as a requirement of the fishing industry in view of its obligation to undertake sustainable and responsible fishing (FAO 1995).

\section{Analysis of seabird-vessel interaction}

The analysis by Torres et al. (2013) of interaction between Buller's albatross and vessels, stratified by fishery type, sex and year, does not take into account many factors known to be of high importance in influencing the nature and duration of the association of albatrosses with fishing vessels. These include: (1) vessel practice with respect to discard and offal management (the nature and frequency of these having a strong influence on the duration of vessel attraction for seabirds; Abraham et al. 2009); (2) use by vessels of measures to deter or prevent albatrosses from accessing fishing gear; (3) time of day of active fishing operations (albatrosses are largely inactive at night; e.g. Jimenez et al. 2009); (4) weather (low wind speed reduces transit and foraging rates in albatrosses; Weimerskirch et al. 2000); (5) the number and species of other seabirds in the vicinity which may compete for space behind a vessel (especially important for small albatrosses like Buller's, readily out-competed by the co-occurring congener whitecapped albatross Thalassarche steadi; Pierre et al. 2012); and (6) the availability of alternative food sources for foraging seabirds in the area. Lack of consideration of these variables severely limits the conclusions drawn by Torres et al. (2013), although they concluded that (2) and (5) were possible explanations for the birds foraging independently of vessels. In addition, the attractiveness of fisheries to seabirds is strongly influenced by the type of fishery. Thus, the low mean inferred overlap rate $(10 \%)$ calculated by Torres et al. (2013) will partly reflect that only $2 \%$ of the vessel events related to longliners (of intense interest to seabirds; Anderson et al. 2011), whereas $90 \%$ related to trawling operations, only parts of which (late stages of hauling and when factory processing is active) are of high interest to seabirds (Sullivan et al. 2006, Watkins et al. 2008).

\section{Fine-scale interaction in relation to bycatch}

Fine-scale analysis has been used effectively to provide useful insights into scale-dependent responses of birds to vessels, variability within and between individuals in relation to response to trawl vessels, and changed flight behaviour when associated with vessels (e.g. Votier et al. 2010, Granadeiro et al. 2011, Torres et al. 2011, Catry et al. 2013).

However, it is self-evident that the finer the scale at which interactions are assessed, the smaller any indices of overlap become. We disagree with the conclusion in Torres et al. (2013) that the risk of interaction is therefore commensurately reduced in reality. Torres et al. (2013) found that Buller's albatross Thalassarche bulleri foraged independently of vessels for a majority of the time and concluded that this contrasted with other studies that documented high rates of albatross bycatch. However, Torres et al. (2013) provide no data on bycatch rates, so direct comparisons (e.g. with the data provided in Croxall 2008 and Anderson et al. 2011) are not possible. Without bycatch data, observations of a low proportion of time spent by albatrosses near vessels should not be used to infer commensurately low rates of bycatch. The events causing bycatch are typically very brief and only involve a small proportion of the seabirds in the vicinity of vessels.

Second, while the authors are correct that congruent simultaneous high densities of seabirds and fishing vessels do not necessarily indicate interaction, they neglect to mention any of the numerous studies, using direct observation, which have shown that high densities of seabirds susceptible to bycatch in the vicinity of trawl vessels do lead to high levels of interaction (Sullivan et al. 2006, Watkins et al. 2008), including examples from New Zealand trawl fisheries (Abraham \& Thompson 2009, Abraham et al. 2009, Pierre et al. 2012).

\section{Scales appropriate for interaction assessment for fisheries management}

The authors conclude that their results 'demonstrate the increased precision and value of quantifying seabird-fishery overlap using a fine-scale approach, rather than relying on conventional large-scale analysis' (Torres et al. 2013, p. 276). However, while a fine-scale approach can provide interesting insights into foraging behaviour, large-scale analysis is needed for effective risk assessment. This is because, inter alia: (1) management measures (e.g. for bycatch mitigation) need to operate across all vessels in a fishery and often across multiple fisheries operating at different spatial and temporal scales; and (2) measures need to apply to all seabird species at risk from the fishing operation (rarely, if ever, a single species of 
albatross) and to individuals of the full range of age, stage and status.

Torres et al. (2013) criticize the large-scale overlap approach for sampling bias and providing only qualitative evaluation. However, the references given to support this statement are all from the pioneering (and preliminary) stages of this work (BirdLife International 2004, Phillips et al. 2006, Copello \& Quintana 2009). Since then, very substantial advances have been made in quantitative analytical methods and their application (BirdLife International 2009, 2010, 2011), including overlap analysis, under the auspices of major regional fisheries management organizations (Waugh et al. 2012, ACAP unpubl. data $^{\mathbf{1}}$ ) and in relation to modelling relationships between fishing effort and albatross population dynamics (Tuck et al. 2001, Thomson et al. 2009). Furthermore, the results of this analysis of Buller's albatross during chick-rearing should not be generalised to other fisheries, situations and species (as occurs in the paper with the substitution of 'seabird' for 'Buller's albatross'). However, the paper does provide interesting insights into aspects of the interactions of adult, chick-rearing Buller's albatrosses with vessels in the subantarctic waters of southern New Zealand.

\section{Conclusion}

We show here that the premises and assertions in Torres et al. (2013) lack a sound basis, leading to misinterpretation of the data. In addition, the paper does not mention the possibility that studies at different scales may be complementary and not interchangeable, that most effective management of fisheries is perforce at relatively large scales, and that pragmatic fishery management at all scales has a greater need of direct observation of interactions than of inferences based on proximities from remote-recording data.

We agree that studying the fine-scale behaviour of seabirds in relation to relatively fine-scale data on the location of fishing vessels provides interesting

1 ACAP (Agreement on the Conservation of Albatrosses and Petrels) (2008) Albatross and petrel distribution within the IATTC area. Paper submitted to the 9th stock assessment review meeting of the Inter-American Tropical Tuna Commission, La Jolla, California, 12-16 May 2008 (available at www.iattc.org/PDFFiles2/SAR-7-05bAlbatross-and-petrel-distribution.pdf)

ACAP (2010) Albatross and petrel distribution in the Atlantic Ocean and overlap with ICCAT longline fishing effort. Paper submitted to the June 2010 ICCAT SubCommittee on Ecosystems, (SCRS/2010/050) insights. However, management of seabird bycatch is best addressed by combining quantification of overlap at medium (and large, where appropriate) scales with data on rates of seabird-vessel interaction and bycatch.

\section{LITERATURE CITED}

Abraham ER, Thompson FN (2009) Warp strike in New Zealand trawl fisheries, 2004-05 to 2006-07. New Zealand Aquatic Environment and Biodiversity, Report no. 33. Ministry of Fisheries, Wellington

- Abraham ER, Pierre JP, Middleton DAJ, Cleal J, Walker NA, Waugh SM (2009) Effectiveness of fish waste management strategies in reducing seabird attendance at a trawl vessel. Fish Res 95:210-219

Anderson ORJ, Small CJ, Croxall JP, Dunn EK, Sullivan BJ, Yates O, Black A (2011) Global seabird bycatch in longline fisheries. Endang Species Res 14:91-106

BirdLife International (2004) Tracking ocean wanderers: the global distribution of albatrosses and petrels. Results from the Global Procellariiform Tracking Workshop, Gordon's Bay, South Africa, 1-5 September 2003. Bird Life International, Cambridge (available at www.birdlife. org/action/science/species/seabirds/tracking.html)

BirdLife International (2009) Draft guidelines for using seabird tracking data to inform the identification of marine IBAs. Results from 'Using seabird tracking data to inform the identification of marine IBAs: a workshop to determine how to achieve this goal', Chize, France, July 2009. BirdLife International, Cambridge (available at www. birdlife.org/datazone/userfiles/file/Marine/ChizeTracking AnalysisReport.pdf)

BirdLife International (2010) Marine IBA toolkit: standardised techniques for identifying priority sites for the conservation of seabirds at sea. Version 1.2. BirdLife International, Cambridge (available at www.birdlife.org/ datazone/userfiles/file/Marine/Marinetoolkitnew.pdf)

BirdLife International (2011) Habitat modelling using satellite tracking data: a workshop to advance this process. Results from a workshop, 21 - 23 September 2011, Coimbra, Portugal. BirdLife International, Cambridge

Catry P, Lemos RT, Brickle P, Phillips RA, Matias R, Granadeiro JP (2013) Predicting the distribution of a threatened albatross: the importance of competition, fisheries and annual variability. Prog Oceanogr 110:1-10

Copello S, Quintana F (2009) Spatio-temporal overlap between the at-sea distribution of southern giant petrels and fisheries at the Patagonian Shelf. Polar Biol 32: $1211-1220$

> Croxall JP (2008) Seabird mortality and trawl fisheries. Anim Conserv 11:255-256

FAO (Food and Agriculture Organization) (1995) Code of conduct for responsible fisheries. FAO, Rome

> Granadeiro JP, Phillips RA, Brickle P, Catry P (2011) Albatrosses following fishing vessels: How badly hooked are they on an easy meal? PLoS ONE 6:e17467

Jiménez S, Domingo A, Brazeiro A (2009) Seabird bycatch in the Southwest Atlantic: interaction with the Uruguayan pelagic longline fishery. Polar Biol 32:187-196

Phillips RA, Silk JRD, Croxall JP, Afanasyev V (2006) Year round distribution of white-chinned petrels from South Georgia: relationships with oceanography and fisheries. 
Biol Conserv 129:336-347

Pierre JP, Abraham ER, Richard Y, Cleal J, Middleton DAJ (2012) Controlling trawler waste discharge to reduce seabird mortality. Fish Res 131-133:30-38

Sullivan BJ, Reid TA, Bugoni L (2006) Seabird mortality on factory trawlers in the Falkland Islands and beyond. Biol Conserv 131:495-504

Thomson RB, Phillips RA, Tuck GN (2009) Modelling the impact of fishery bycatch on wandering and blackbrowed albatrosses of South Georgia: preliminary results. ICCAT Coll Sci Pap 64:2342-2382

Torres LG, Thompson DR, Bearhop S, Votier SC, Taylor GA, Sagar PM, Robertson BC (2011) White-capped albatrosses alter fine-scale foraging behavior patterns when associated with fishing vessels. Mar Ecol Prog Ser 428: 289-301

Torres LG, Sagar PM, Thompson DR, Phillips RA (2013) Scaling down the analysis of seabird-fishery interactions. Mar Ecol Prog Ser 473:275-289

Editorial responsibility: Matthias Seaman,

Oldendorf/Luhe, Germany
Tuck GN, Polacheck T, Croxall JP, Weimerskirch H (2001) Modelling the impact of fishery by-catches on albatross populations. J Appl Ecol 38:1182-1196

> Votier SC, Bearhop S, Witt MJ, Inger R, Thompson DR, Newton J (2010) Individual responses of seabirds to commercial fisheries revealed using GPS tracking, stable isotopes and vessel monitoring systems. J Appl Ecol 47: 487-497

Watkins BP, Petersen SL, Ryan PG (2008) Interactions between seabirds and deep-water hake trawl gear: an assessment of impacts in South African waters. Anim Conserv 11:247-254

> Waugh SM, Filippi DP, Kirby DS, Abraham E, Walker N (2012) Ecological risk assessment for seabird interactions in Western and Central Pacific longline fisheries. Mar Policy 36:933-946

> Weimerskirch H, Guionnet T, Martin J, Shaffer SA, Costa DP (2000) Fast and fuel-efficient? Optimal use of wind by flying albatrosses. Proc Biol Sci 267:1869-1874

Submitted: June 5, 2013; Accepted: October 15, 2013

Proofs received from author(s): October 17, 2013 